\title{
Biocompatibility assessment of single-walled carbon nanotubes using Saccharomyces cerevisiae as a model organism
}

\author{
Song Zhu, Fei Luo, Jian Li, Bin Zhu* and Gao-Xue Wang * (i)
}

\begin{abstract}
Background: Single-walled carbon nanotubes (SWCNTs) have many potential applications in various fields. Especially, the unique physicochemical properties make them as the prime candidates for applications in biomedical fields. However, biocompatibility of SWCNTs has been a major concern for their applications. In the study, biocompatibility of oxidized SWCNTs (O-SWCNTS) was assessed using Saccharomyces cerevisiae (S. cerevisiae) as a model organism.

Results: Cell proliferation and viability were significantly changed after exposure to O-SWCNTs (188.2 and $376.4 \mathrm{mg} / \mathrm{L}$ ) for $24 \mathrm{~h}$. O-SWCNTs were internalized in cells and distributed in cytoplasm, vesicles, lysosomes and cell nucleus. The average O-SWCNTs contents in S. cerevisiae were ranged from 0.18 to $4.82 \mathrm{mg} / \mathrm{g}$ during the exposure from 0 to $24 \mathrm{~h}$, and the maximum content was reached at $18 \mathrm{~h}$ after exposure. Both penetration and endocytosis were involved in the internalization of O-SWCNTs in S. cerevisiae, and endocytosis was the main pathway. Cellular structures and morphology were changed after exposure to O-SWCNTs, such as undulating appearance at the membrane, shrinking of the cytosol, increased numbers of lipid droplets and disruption of vacuoles. ROS and antioxidant enzymes activities were observably changed following exposure. For the treatment at $376.4 \mathrm{mg} / \mathrm{L}, 20.8 \%$ of the total cells was undergone apoptosis. Decrease of mitochondrial transmembrane potential and leakage of cytochrome $c$ from mitochondria were observed after exposure. Moreover, expression levels of apoptosis-related genes were significantly increased.
\end{abstract}

Conclusions: O-SWCNTS can internalize in S. cerevisiae cells via direct penetration and endocytosis, and distribute in cytoplasm, vesicles, lysosomes and cell nucleus. Besides, O-SWCNTs (188.2 and $376.4 \mathrm{mg} / \mathrm{L}$ ) can induce apoptosis in S. cerevisiae cells, and oxidative stress is involved in activation of the mitochondria-dependent apoptotic pathway.

Keywords: Carbon nanotubes, Yeast, Uptake, Oxidative stress, Apoptosis

\section{Background}

Single-walled carbon nanotubes (SWCNTs) are important nanomaterials that have potential to be used for a variety of applications in many fields [10]. Especially, they have the potential to revolutionize biomedical research. Merging of SWCNTs with medicine presents an unprecedented opportunity for developing novel materials that can improve treatment and diagnosis of diseases. Several highly promising applications have been reported

*Correspondence: zhubin1227@126.com; wanggaoxue@126.com College of Animal Science and Technology, Northwest A\&F University, Xinong Road 22nd, Yangling 712100, Shaanxi, China in some studies, such as drug delivery, gene therapy, growth substrates, tissue scaffolds and biological imaging $[2,3,17]$. When considering their biomedical applications, SWCNTs are expected to have an intrinsically low systemic toxicity [18]. Therefore, the biological, environmental and safe profiles of SWCNTs need to be thoroughly characterized and understood before their broadly used.

A growing number of studies have assessed the potential toxicity of SWCNTs to a number of cell types and organisms [12]. Some studies reported that SWCNTs can internalize in cells and induce cell apoptosis/necrosis. Besides, one of the most common SWCNTs mechanisms 
that lead to cytotoxicity is related to oxidative stress that can cause mitochondrial impairment and apoptosis [9, 30, 36]. The uptake pathways and intracellular distribution of SWCNTs have also been investigated in previous studies. Data so far supported that endocytosis is the major uptake pathway of SWCNTs in mammalian cells, and SWCNTs are distributed in cytoplasm, lysosomes, mitochondria and cell nucleus [33]. The complexity of SWCNTs toxicity is attributed to various parameters, such as purity, length, agglomeration and surface functionalization of SWCNTs, especially, different types of cells and organisms were used in the toxicity studies [33, 41]. Owing to their lightweight characteristics, SWCNTs are ubiquitously distributed in the environment, including air, water and soil. Various kinds of organisms that active in the environment are at risk of SWCNTs. Therefore, representative organisms are necessary to systematic study the uptake, distribution, accumulation and biocompatibility of SWCNTs.

Saccharomyces cerevisiae (S. cerevisiae) is one of the most intensively used unicellular eukaryotic model organisms in molecular and cell biology studies. Its cellular structure and functional organization share much similarity with cells of plants and animals, furthermore, it also has a short generation time and can be easily cultured like bacteria. Therefore, toxicity studies using $S$. cerevisiae as a model organism can provide clues to understand nanotoxicity in higher organisms and bacteria $[14,20,34]$. S. cerevisiae is a widely used model organism for the study of oxidative stress and apoptosis [7], and its genome was sequenced [15]. Thus lots of data and genes are available for mechanistic studies. It has been widely used as a model organism in the toxicological studies of nanomaterials, such as $\mathrm{TiO}_{2}, \mathrm{ZnO}, \mathrm{CuO}, \mathrm{Al}_{2} \mathrm{O}_{3}$, $\mathrm{Mn}_{2} \mathrm{O}_{3}, \mathrm{CeO}_{2}$ and $\mathrm{SiO}_{2}$ nanoparticles [14, 20, 34]. In addition, we have investigated the effects of multi-walled carbon nanotubes (MWCNTs), graphene oxide (GO) and $\alpha-\mathrm{Fe}_{2} \mathrm{O}_{3}$ nanoparticles on $S$. cerevisiae [45-47]. Results showed that $S$. cerevisiae is a suitable model organism for toxicological studies of nanomaterials.

In the study, biocompatibility of oxidized SWCNTs (O-SWCNTs) was assessed using S. cerevisiae as a model organism. Based on previous studies, we hypothesized that (1) O-SWCNTs would be internalized and well distributed in S. cerevisiae; (2) both penetration and endocytosis would involve in the internalization of O-SWCNTs in S. cerevisiae; (3) O-SWCNTs would induce apoptosis in S. cerevisiae cells; and (4) oxidative stress would involve in activation of the mitochondria-dependent apoptotic pathway. The study contributes to a better understanding of the O-SWCNTs biocompatibility, and lays foundation for their applications.

\section{Methods}

\section{Characterization of O-SWCNTs}

SWCNTs (Chengdu Organic Chemicals Co., Ltd., China) were purified and oxidized according to our previous study [44]. O-SWCNTs (600 mg) were weighed on aluminum foil and dispersed in $1 \mathrm{~L}$ YPD medium (1\% yeast extract, $2 \%$ peptone and $2 \%$ glucose). The resulting suspension was sonicated for $2 \mathrm{~h}$ at $100 \mathrm{~W}$ with a $50 \%$ on/ off cycle. Following the sonication, the suspension was centrifuged at $12,000 \mathrm{~g}$ for $2 \mathrm{~h}$. The supernatant was collected, and concentration of O-SWCNTs was determined by Raman spectrophotometer. Raman spectrophotometer is a useful tool to quantify CNTs due to the normalised G-band areas show linear concentration behaviour in accordance with Beer's law [4, 16, 39]. For the quantitative analysis, a standard curve between the concentrations of O-SWCNTs and the normalised G-band areas was established. Then, the supernatant was pipetted into a square quartz groove (side length: $5 \mathrm{~mm}$, height: $1 \mathrm{~mm}$ ) and dried in vacuum at $80{ }^{\circ} \mathrm{C}$. Contents of O-SWCNTs were measured using the Raman spectrophotometer with an excitation wavelength of $785 \mathrm{~nm}$, and calculated by the standard curve. The supernatant was diluted to create suspensions with a series of concentrations by double dilution method. All suspensions were sterilized and sonicated again before used. For SWCNTs characterization, both SEM (Hitachi S-4800, Japan) and TEM (JEM1200EX, Japan) were used to observe the shape of O-SWCNTs. The purity, chemical states and elemental compositions of pristine SWCNTs (P-SWCNTs) and O-SWCNTs were analyzed using Raman spectrophotometer (Longjumeau Cedex, France) and XPS (PHI-5600, Russia).

\section{Cell proliferation and viability}

Saccharomyces cerevisiae was cultivated in O-SWCNTs suspensions with constant shaking (160 rpm) at $30{ }^{\circ} \mathrm{C}$, and the inoculation quantity was approximately $1 \times 10^{5}$ cells $/ \mathrm{mL}$. For proliferation assays, cells were counted at $0,3,6,9,12,15,18,21$ and $24 \mathrm{~h}$ with a hematocytometer under an optical microscope (Olympus Optical Co., Ltd., Tokyo, Japan). To check the effect of O-SWCNTs on cell viability, cells were collected following exposure for $24 \mathrm{~h}$ and stained with $1 \mathrm{mg} / \mathrm{mL}$ Trypan Blue (Sigma, USA) for 3-5 min. The stained cells and total cells were counted under the microscope, and mortality rate was calculated as a ratio between stained cells and total cells. All measurements were carried out eight times. 


\section{Internalization, distribution and uptake kinetics of O-SWCNTs in S. cerevisiae}

Internalization and distribution of O-SWCNTs in S. cerevisiae were observed using the TEM according to Bayat et al. [6]. In order to measure the uptake kinetics, contents of O-SWCNTs in S. cerevisiae were quantitatively assessed after exposure for 0, 3, 6, 9, 12, 15, 18, 21 and $24 \mathrm{~h}$. Dry weight of $S$. cerevisiae cells was measured before the quantitative assessment. Briefly, cells treated without O-SWCNTs were collected and counted under the microscope. Then, the cells were dried using a freeze dryer (FD5-3, GOLD-SIM) and weighted using a balance (Sartorius Stedim Biotech GmbH, Germany). After that, the average weight of a single cell was calculated. The O-SWCNTs contents were measured based on the dry weight of $S$. cerevisiae, reflecting the total cell burden across the exposure from 0 to $24 \mathrm{~h}$. For the measurement, cells were collected using density gradient centrifugation [47] at each time point, and then counted under the microscope. The cells were pipetted into a square quartz groove (side length: $5 \mathrm{~mm}$; height: $1 \mathrm{~mm}$ ), and then dried in vacuum at $80{ }^{\circ} \mathrm{C}$. Contents of O-SWCNTs were measured using the Raman spectrophotometer with an excitation wavelength of $785 \mathrm{~nm}$, and calculated by the standard curve. All measurements were carried out three times.

\section{Uptake mechanism}

To elucidate whether O-SWCNTs enter into $S$. cerevisiae via endocytosis, cells were exposure to O-SWCNTs suspension in the presence of $5 \%(\mathrm{v} / \mathrm{v})$ ethanol and at $4{ }^{\circ} \mathrm{C}$, respectively. O-SWCNTs in $S$. cerevisiae were quantitatively measured using Raman spectrophotometer as described above. Moreover, expression levels of endocytosis-related genes (END3, END6, Sla2 and Rsp5) were measured by Real-Time PCR using ribosomal 18S RNA (18S rRNA) as internal standard. Primers for the genes and cycling conditions were designed as previous studies [47]. Relative expression was obtained by using the $2^{-\Delta \Delta \mathrm{Ct}}[40]$ method and normalized to the expression of the internal standard gene $18 \mathrm{~S}$ rRNA in the same sample. All measurements were carried out three times.

\section{Effects of O-SWCNTs on cellular structure}

After exposure for $24 \mathrm{~h}$, cells were collected using density gradient centrifugation and washed with PBS $(\mathrm{pH}=7.1)$. The cells were fixed with $2.5 \%$ glutaraldehyde in PBS at $4{ }^{\circ} \mathrm{C}$ for $24 \mathrm{~h}$ and then adhered onto a piece of glass using polylysine. Afterwards, cells were dehydrated through a graded ethanol series (30-90\%, $2 \times 100 \%$; 15-20 min each) and replaced using isoamyl acetate. The samples were dried overnight and coated with a thin layer of gold, and observed using the SEM. Moreover, effects of O-SWCNTs on cellular structure were also checked using TEM according to Bayat et al. [6].

\section{ROS and antioxidant enzymes activities}

After exposure for $24 \mathrm{~h}$, approximately $1 \times 10^{8}$ cells were collected. The cells were mixed with glass beads $(0.3-$ $0.4 \mathrm{~mm}$ ) and thoroughly ruptured by vigorous vortexing for 5-10 $\mathrm{min}$. After vortexing, the homogenates were centrifuged $\left(12,000 \mathrm{rpm}, 4{ }^{\circ} \mathrm{C}\right)$ for $10 \mathrm{~min}$. The supernatants were collected for ROS and antioxidant enzymes (SOD, CAT and GPx) activities measurements. Total protein, ROS, SOD, CAT and GPx activities were measured using kits (Nanjing Jiancheng Bioengineering Institute, Nanjing, China) according to manufacturer's instructions, and detected by a microplate reader (Multiskan MK3, Thermo Labsystems Co., Beverly, MA). All measurements were carried out three times.

\section{Apoptosis assay}

After exposure for $24 \mathrm{~h}$, approximately $2 \times 10^{5}$ cells were collected from each treatment and stained with annexin-V-FITC $(5 \mu \mathrm{L})$ and PI $(5 \mu \mathrm{L})$ following the manufacturer's instruction. Following the staining, flow cytometry (Beckman Coulter Inc., United States) analysis was immediately conducted. FITC fluorescence (FL1) and PI fluorescence (FL2) of each cell were quantitated using the Cell Quest Pro ${ }^{\circledR}$ software (BD, Germany).

\section{Mitochondrial transmembrane potential}

Mitochondrial transmembrane potential (MTP, $\Delta \Psi_{\mathrm{m}}$ ) was detected using JC-1 (Beyotime Biotech, Nantong, China) as described in previous studies [8, 35]. Briefly, cells were collected following exposure for $24 \mathrm{~h}$. The cells were incubated with JC-1 following the manufacturer's instruction and analyzed using a microplate reader (Multiskan MK3, Thermo Labsystems Co., Beverly, MA). Ratios between red and green fluorescent were calculated, and results were shown as percentage between the ratios of treatments and that of the control. All measurements were carried out three times.

\section{Cytochrome c leakage from mitochondria}

After exposure for $24 \mathrm{~h}$, approximately $1 \times 10^{6}$ cells were collected from each treatment. The cells were ruptured as described above, and supernatants were collected. A small amount of $\mathrm{Na}_{2} \mathrm{~S}_{2} \mathrm{O}_{3}$ was added into the supernatants in order to keep cytochrome $\mathrm{c}$ in the reduction state. Absorbance of cytochrome $\mathrm{c}$ was measured at $540 \mathrm{~nm}$ using a UV-visible spectrophotometer (UV2200, Shimadzu, Japan). All measurements were carried out three times. 


\section{Expression of apoptosis-related genes}

Expression levels of apoptosis-related genes (SOD, Yca1, Nma111 and Nuc1) were measured by Real-Time PCR as described above. All measurements were carried out three times.

\section{Statistical analysis}

Data were expressed as mean \pm standard deviation (SD) and analyzed using SPSS Version 11.0 software package (SPSS Inc., Chicago, IL). Differences between the controls and treatments were analyzed using one-way ANOVA followed by Tukey's test, where $p<0.05$ was considered significant.

\section{Results and discussion}

\section{Characterization of SWCNTs}

The complexity of SWCNTs toxicity is attributed to various parameters, such as concentration, purity, length and surface functionalization [33]. Therefore, these parameters should be well characterized before the toxicity assessment. In the study, O-SWCNTs suspension was sonicated and centrifuged to acquire well-dispersed supernatant. Concentration of O-SWCNTs in the supernatant was $376.4 \mathrm{mg} / \mathrm{L}$. The supernatant was diluted to create suspensions $(23.5,47.1,94.1$ and $188.2 \mathrm{mg} / \mathrm{L}$ ) by double dilution method. As shown in SEM (Fig. 1a) and TEM (Fig. 1b) images, O-SWCNTs were fibrous with varying lengths. According to statistical analysis of TEM images, the average length of O-SWCNTs was $263 \mathrm{~nm}$, and shorter than the average length of P-SWCNTs $(3.16 \mu \mathrm{m})$. As shown in Fig. 1c, typical G (around $1580 \mathrm{~cm}^{-1}$ ) and D band (around $1303 \mathrm{~cm}^{-1}$ ) of CNTs [11] were identified from the raman spectra of P- and O-SWCNTs. D/G band intensity ratio $\left(\mathrm{I}_{\mathrm{D}} / \mathrm{I}_{\mathrm{G}}\right)$ can be used to monitor the defects of CNTs as it is increased with the defects increasing $[28,31]$. The $\mathrm{I}_{\mathrm{D}} / \mathrm{I}_{\mathrm{G}}$ ratios of P-SWCNTs and O-SWCNTs were 0.82 and 1.32, indicating that defects of SWCNTs were increased following oxidation. Figure $1 \mathrm{~d}$ shows XPS spectra of P- and O-SWCNTs, indicating SWCNTs surface was consisted of carbon $(284 \mathrm{eV})$ and oxygen $(532 \mathrm{eV})$. Surface oxygen contents for P- and O-SWCNTs were 3.32 and 14.6 atomic \%, respectively, suggesting the oxidation was sufficient. There are small amounts of iron [711 (Fe 2 $\left.\mathrm{p}_{1 / 2}\right)$ and $725\left(\mathrm{Fe} 2 \mathrm{p}_{3 / 2}\right) \mathrm{eV}$ ], cobalt $(782 \mathrm{eV})$ and nickel $(850 \mathrm{eV})$ in P-SWCNTs which not found in O-SWCNTs, indicating that O-SWCNTs were free from impurities following oxidation. All the results showed that the oxidation of SWCNTs was sufficient and the impurities were removed.

\section{Effects of O-SWCNTs on cell proliferation and viability}

After exposure to O-SWCNTs suspensions, cell proliferation showed a dose-dependent inhibition (Fig. 2a), and was significantly inhibited $(p<0.01)$ at 188.2 and
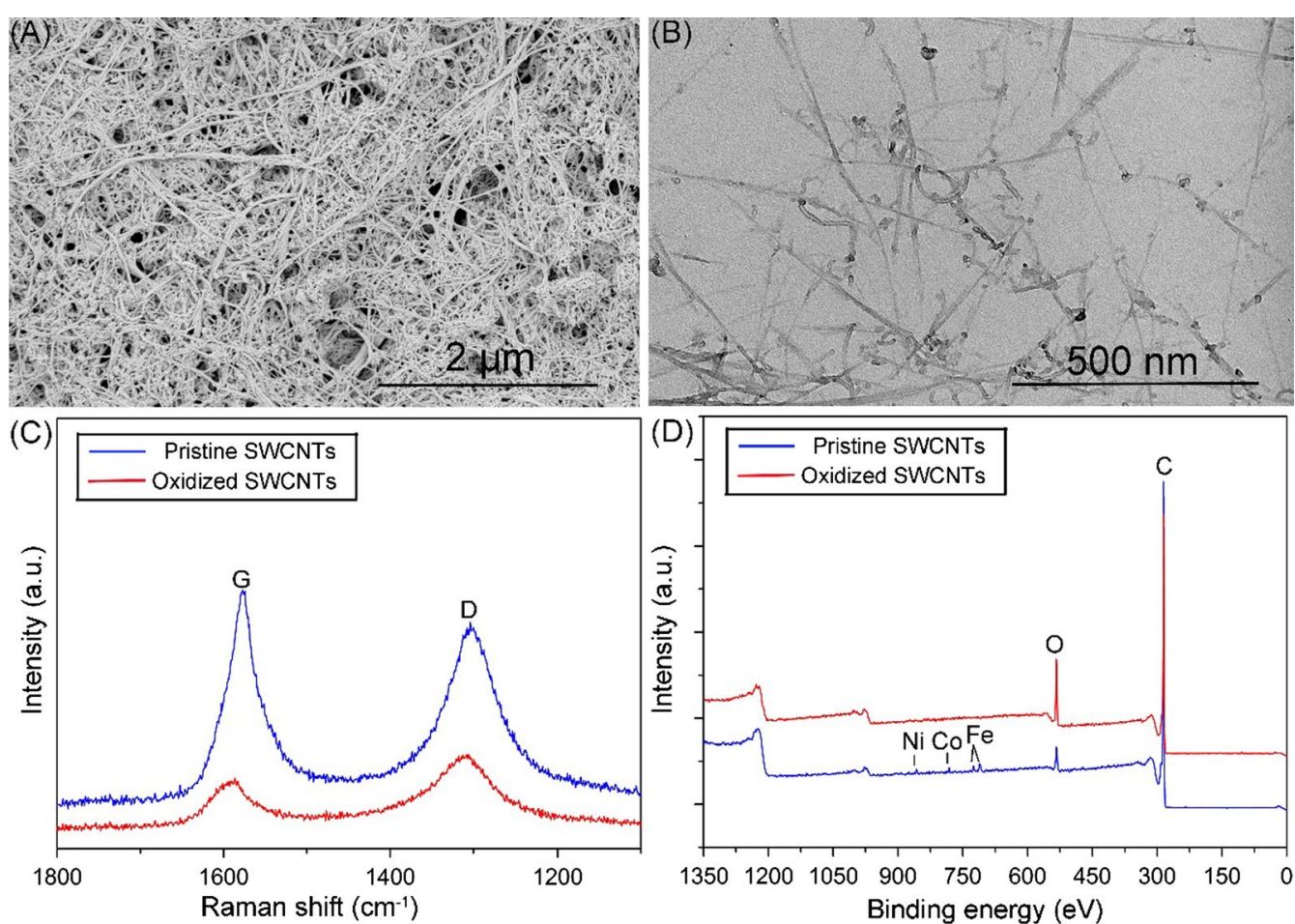

Fig. 1 Characterization of SWCNTS. SEM (a) and TEM (b) images of O-SWCNTs. Raman (c) and XPS (d) spectra of P-SWCNTs and O-SWCNTs 

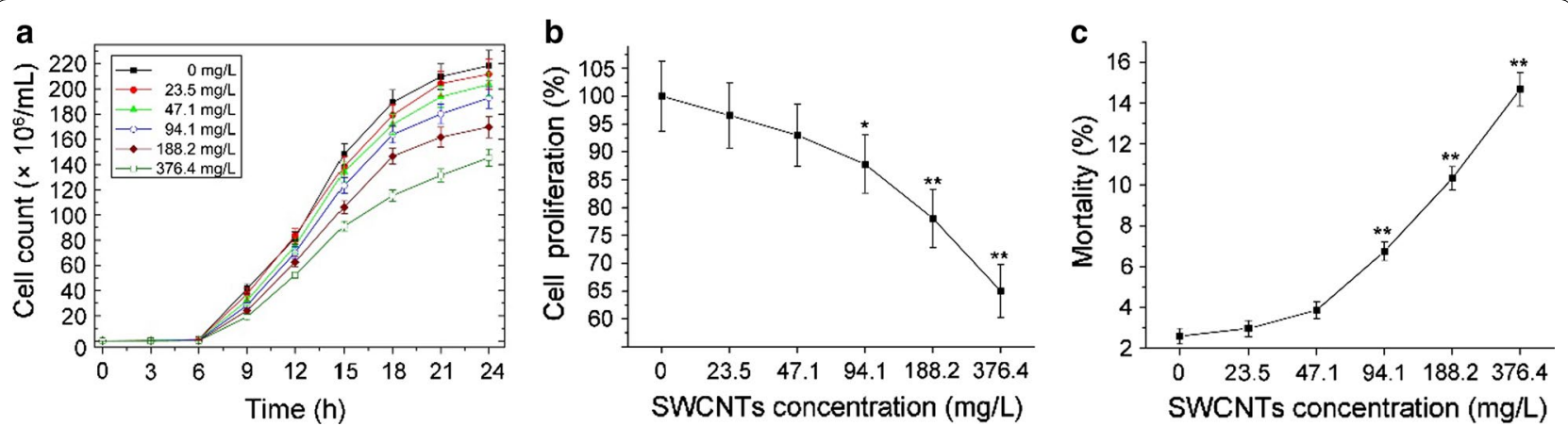

Fig. 2 a Growth curves of S. cerevisiae exposed to 0-376.4 mg/L O-SWCNTs suspensions. Effects of O-SWCNTs on cell proliferation (b) and viability (c) after exposure for $24 \mathrm{~h}$. Values are presented as mean \pm SD. Values that are significantly different from the control are indicated by asterisks (oneway ANOVA, ${ }^{*} p<0.05 ;{ }^{* *} p<0.01$ )

$376.4 \mathrm{mg} / \mathrm{L}$ (Fig. 2b). The cells proliferation at $376.4 \mathrm{mg} / \mathrm{L}$ was $64.9 \%$ compared with the control after exposure for $24 \mathrm{~h}$. Mortality was notably increased $(p<0.01)$ at $94.1-$ $376.4 \mathrm{mg} / \mathrm{L}$, and was $14.7 \%$ after exposure to $376.4 \mathrm{mg} / \mathrm{L}$ for $24 \mathrm{~h}$ (Fig. 2c). Effects of MWCNTs on $S$. cerevisiae have been investigated in our previous study [47]. Proliferation and mortality after exposure to $400 \mathrm{mg} / \mathrm{L} \mathrm{MWC-}$ NTs were $72.2 \%$ (compared with the control) and 6.1\%, respectively. Therefore, these data indicated that SWCNTs possess a higher toxicity file than MWCNTs.

\section{Internalization, distribution and uptake kinetics of O-SWCNTs in S. cerevisiae}

Several studies about the distribution of SWCNTs have been reported and showed that SWCNTs distributed in the cytoplasm, lysosomes, mitochondria, endosome-like vesicles and cell nucleus [33, 37]. The internalization, distribution and uptake kinetics of O-SWCNTs in S. cerevisiae were checked in the study. As shown in Fig. 3a, O-SWCNTs were firstly adsorbed onto the cell wall surface and then penetrated across the cell wall (Fig. 3b) and membrane (Fig. 3c). Subsequently, O-SWCNTs entered into the cells and distributed in cytoplasm (Fig. 3d, e), vesicles (Fig. 3e), lysosomes (Fig. 3e) and cell nucleus (Fig. 3f). These results were similar to that reported by Porter et al. [37], who demonstrated that SWCNTs distributed in cytoplasm, lysosomes, endosome-like vesicles and cell nucleus of human monocyte-derived macrophages [37]. We investigated the distribution of MWCNTs in S. cerevisiae, and showed that MWCNTs were distributed in the perinuclear region without entering into cell nucleus [47]. The difference may be due to that SWCNTs have a smaller diameter and stronger penetrability than MWCNTs.

As shown in Fig. 3g, the average length of SWCNTs in cells was around $110 \mathrm{~nm}$, which was shorter than the SWCNTs $(263 \mathrm{~nm})$. The result indicated that shorter
SWCNTs are more easily enter into cells. The uptake kinetics of O-SWCNTs in S. cerevisiae was shown in Fig. 3h. The average O-SWCNTs contents were ranged from 0.18 to $4.82 \mathrm{mg} / \mathrm{g}$, and the maximum content was reached at $18 \mathrm{~h}$ after exposure. A decrease was observed from 18 to $24 \mathrm{~h}$ probably due to the discharge of O-SWCNTs. Uptake kinetics of MWCNTs in S. cerevisiae was investigated in previous study. Result showed that the maximum MWCNTs content was reached at $3 \mathrm{~h}$ after exposure [47], indicating that SWCNTs presented a slower uptake compared with MWCNTs.

\section{Uptake mechanism}

Several findings suggested that endocytosis is the major uptake pathway of SWCNTs in mammalian cells [19, 33]. To investigate whether endocytosis occurs for the internalized O-SWCNTs in S. cerevisiae cells, we studied the effect of endocytosis inhibiting conditions (5\% ethanol [23] and $4{ }^{\circ} \mathrm{C}$ [29]) on cellular uptake. As shown in Fig. $4 \mathrm{a}, \mathrm{b}$, the contents of O-SWCNTs in cells were significantly decreased after incubation with $5 \%$ ethanol $(2.16 \mathrm{mg} / \mathrm{g})$ and at $4{ }^{\circ} \mathrm{C}(1.33 \mathrm{mg} / \mathrm{g})$ compared with the control $(4.82 \mathrm{mg} / \mathrm{g})$. Contents of O-SWCNTs in cells were reduced by 55.2 and $72.4 \%$ after incubation with $5 \%$ ethanol and at $4{ }^{\circ} \mathrm{C}$ compared with the control, respectively. Besides, expression levels of endocytosis-related genes [END3 (Fig. 4c), END6 (Fig. 4d), Sla2 (Fig. 4e) and Rsp5 (Fig. 4f)] were increased after exposure to 0-376.4 mg/L O-SWCNTs suspensions. These data indicated that cellular uptake is predominantly an endocytosis process. Similar result was reported in other studies [27, 33].

Figure 3 clearly illustrated the penetration and internalization of O-SWCNTs into the cells. Direct penetration through the cell wall and membrane could be designated as one of the routes to deliver the O-SWCNTs into the cytoplasm. It was demonstrated that CNTs could readily 

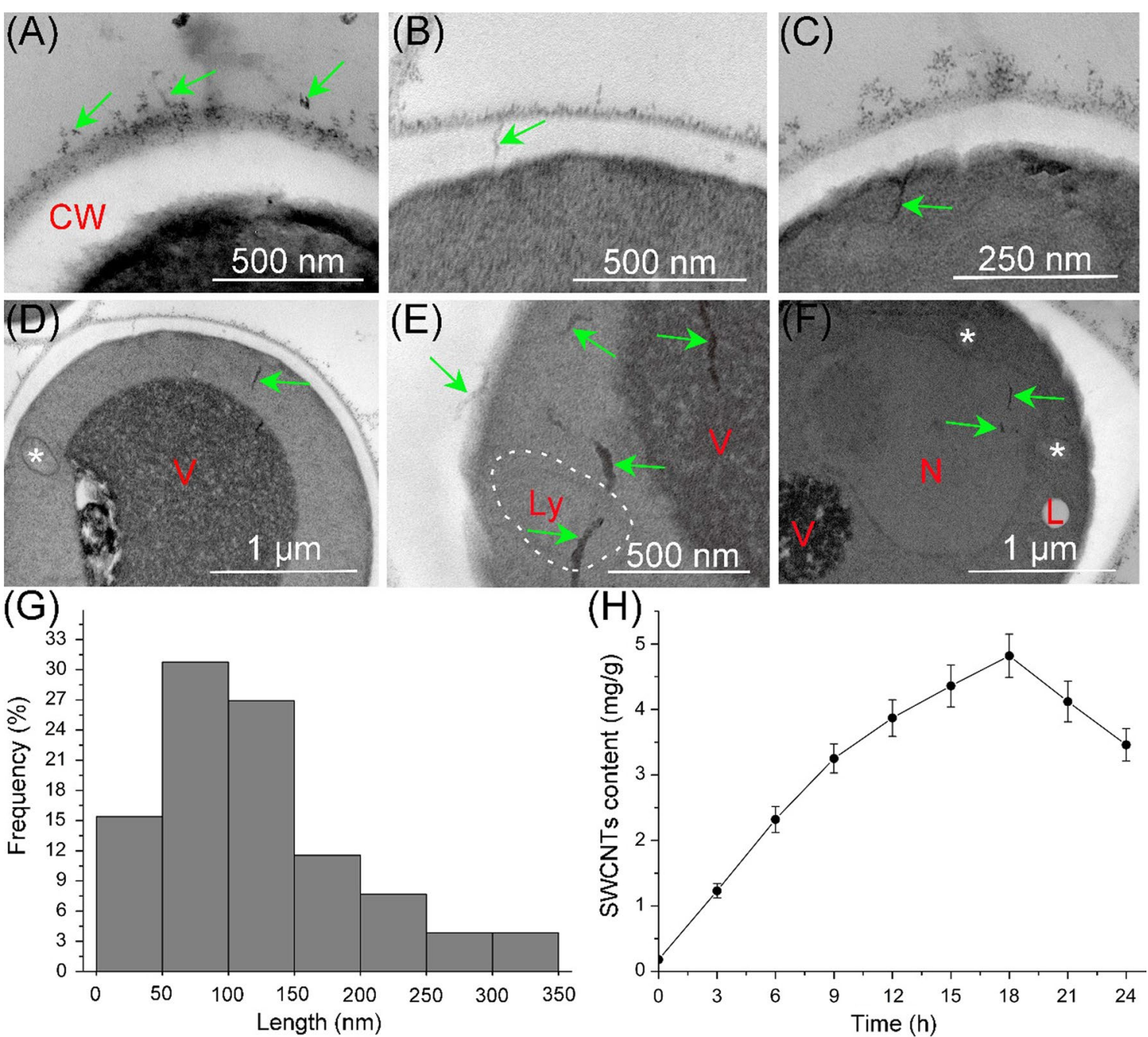

Fig. 3 Internalization, distribution and uptake kinetics of O-SWCNTs (green arrows) in S. cerevisiae. O-SWCNTs were firstly adsorbed onto the cell wall surface (a) and then penetrated across the cell wall (b) and membrane (c). O-SWCNTs entered into the cells and distributed in cytoplasm (d), vesicles and lysosomes (e), and cell nucleus (f). $\mathbf{g}$ Length distribution of O-SWCNTs in S. cerevisiae cells. $\mathbf{h}$ Uptake kinetics of O-SWCNTs in S. cerevisiae cells. Values are presented as mean \pm SD. CW cell wall, $V$ vesicle, Ly lysosome, $N$ nucleus, $L$ lipid droplet, ${ }^{*}$ mitochondrion

permeate through the cell wall, driven by van der Waals forces or hydraulic forces [42]. Based on the combined results of Figs. 3 and 4, it can be concluded that internalization of O-SWCNTs in S. cerevisiae cells via: (1) direct penetration. O-SWCNTs were firstly adsorbed onto the cell wall surface, and then penetrated across the cell wall and membrane. After the penetration, O-SWCNTs distributed in the cytoplasm, vesicles, lysosomes and cell nucleus; (2) endocytosis. O-SWCNTs adsorbed and penetrated across the cell wall. Subsequently, the cell membrane was invaginated and wrapped up the O-SWCNTs. O-SWCNTs entered into the cells within the endosomes. The endosomes merged with lysosomes, and then lysosomes merged with vacuoles. The findings are somewhat similar to the results of previous studies $[1,47]$.

\section{Effects of O-SWCNTs on cellular structure}

One of the CNTs-cytotoxicity mechanisms was proposed to be CNTs-induced cellular structure damages $[22,33]$. As shown in Fig. 5a, surface of cells treated without O-SWCNTs was plump and smooth. After exposure to O-SWCNTs, cells were deformed and shrank (Fig. 5b, c). Cell wall of crinkled cell was incrassate, and its thickness was not uniform (Fig. 5d). Other damages, such as increased numbers of lipid droplets (Fig. 5e) and disruption of vacuoles (Fig. 5f) were also observed. Our findings are similar to the results reported by Bayat et al. [6], who investigated the effects of engineered nanoparticles on the cellular structure of S. cerevisiae. They demonstrated that increase in the number of lipid droplets, disruption or lack of vacuoles, shrinking of the cytosol 

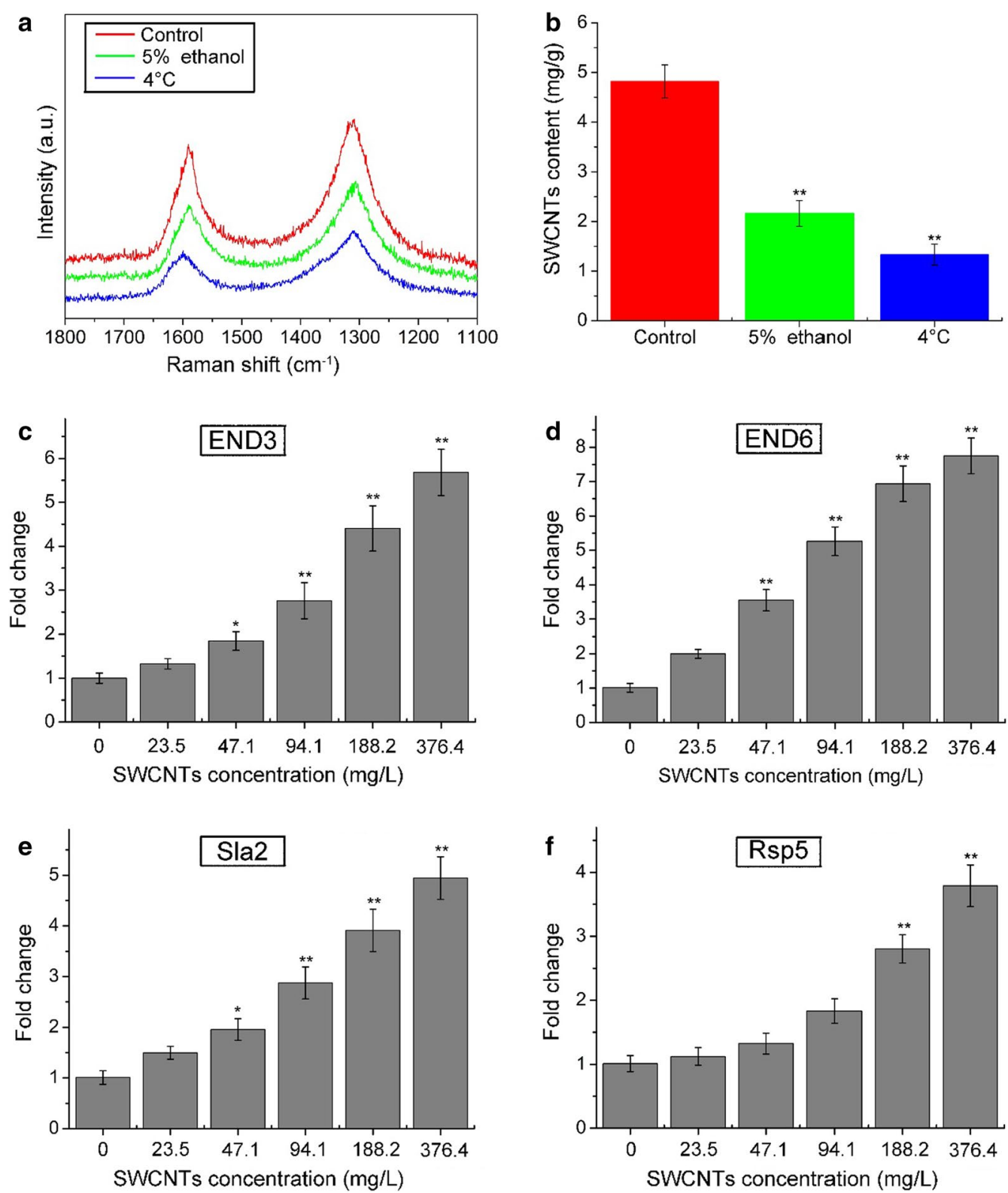

Fig. 4 Internalization of O-SWCNTs in S. cerevisiae cells via endocytosis. Raman spectra (a) and contents (b) of O-SWCNTs uptake by S. cerevisiae cells under different treatment (control, 5\% ethanol and $4^{\circ} \mathrm{C}$ ). Expression levels of endocytosis-related genes [END3 (c), END6 (d), Sla2 (e) and Rsp5 (f)] after exposure to 0-376.4 mg/L O-SWCNTs suspensions. Values are presented as mean \pm SD. Values that are significantly different from the control are indicated by asterisks (one-way ANOVA, ${ }^{*} p<0.05 ;{ }^{* *} p<0.01$ )

and undulating appearance at the membrane were visible after exposure to $\mathrm{CuO}$ and $\mathrm{Ag}$ nanoparticle [6].

\section{ROS and antioxidant enzymes activities}

SWCNTs internalized into the cells would induce oxidative stress by producing ROS, which could undoubtedly be one of the factors responsible for the acceleration of cell apoptosis or death. Exposure to SWCNTs has been associated with altered levels of components in the antioxidant defense system, such as CAT, SOD and GPx $[9,25,30]$. Production of ROS and antioxidant enzymes activities were detected in the study. As shown in Fig. 6a, ROS was observably $(p<0.01)$ increased following exposure to 188.2 and $376.4 \mathrm{mg} / \mathrm{L}$ O-SWCNTs compared with the control. CAT activity showed a dose-dependent increase and dramatically increased $(p<0.01)$ at 188.2 and $376.4 \mathrm{mg} / \mathrm{L}$ (Fig. 6b). Interestingly, SOD (Fig. 6c) and GPx (Fig. 6d) activities were firstly increased and follow 

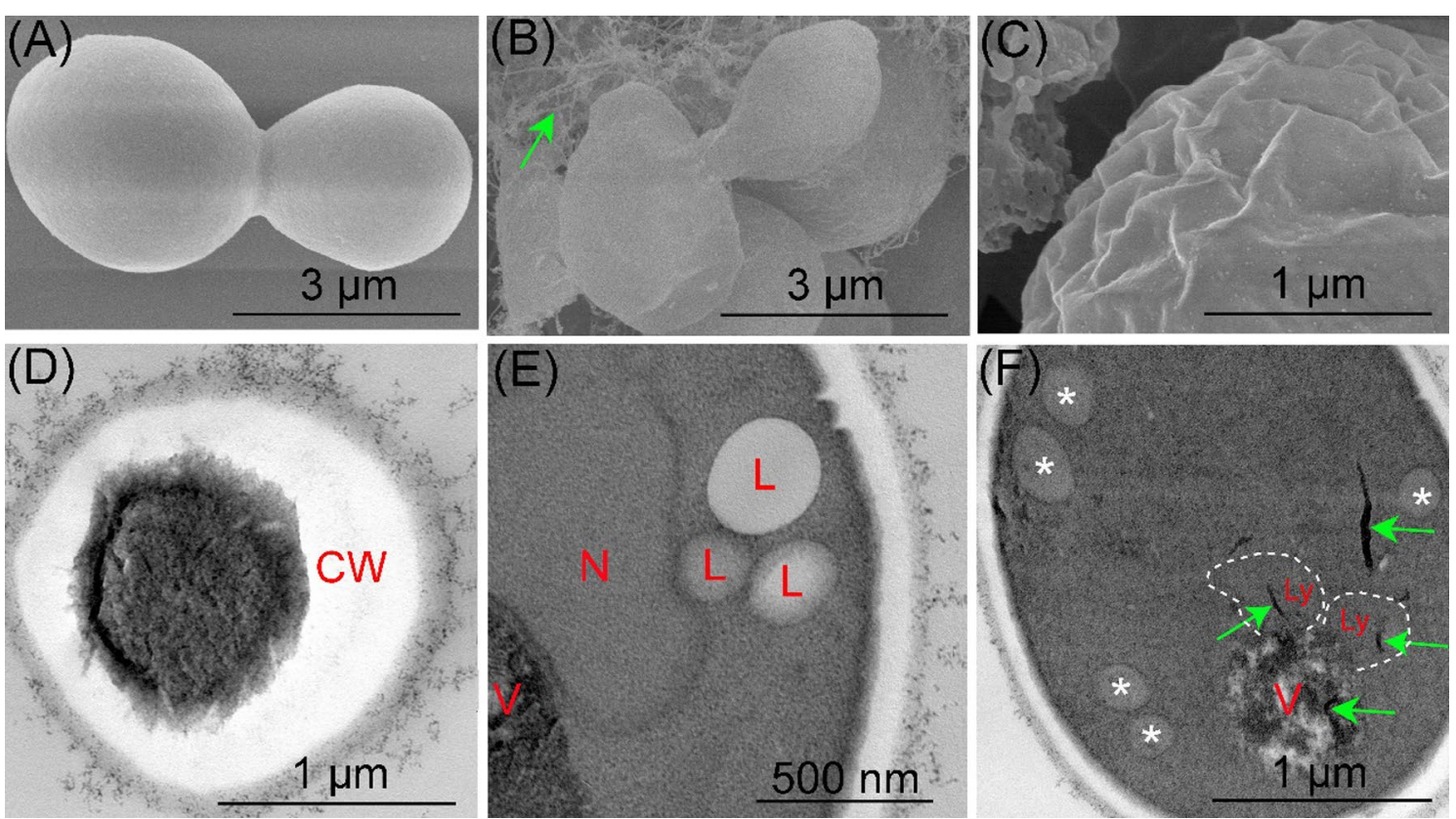

Fig. 5 Effects of O-SWCNTs (green arrows) on cellular structure. a Surface of cells treated without O-SWCNTs was plump and smooth. b, c After exposure to O-SWCNTs, cells were deformed and shrank. d Cell wall of crinkled cell was incrassate, and its thickness was not uniform. Increased numbers of lipid droplets (e) and disruption of vacuoles (f) were also observed. CW cell wall, $V$ vesicle, N nucleus, L lipid droplet, Ly lysosome, ${ }^{*}$ mitochondrion
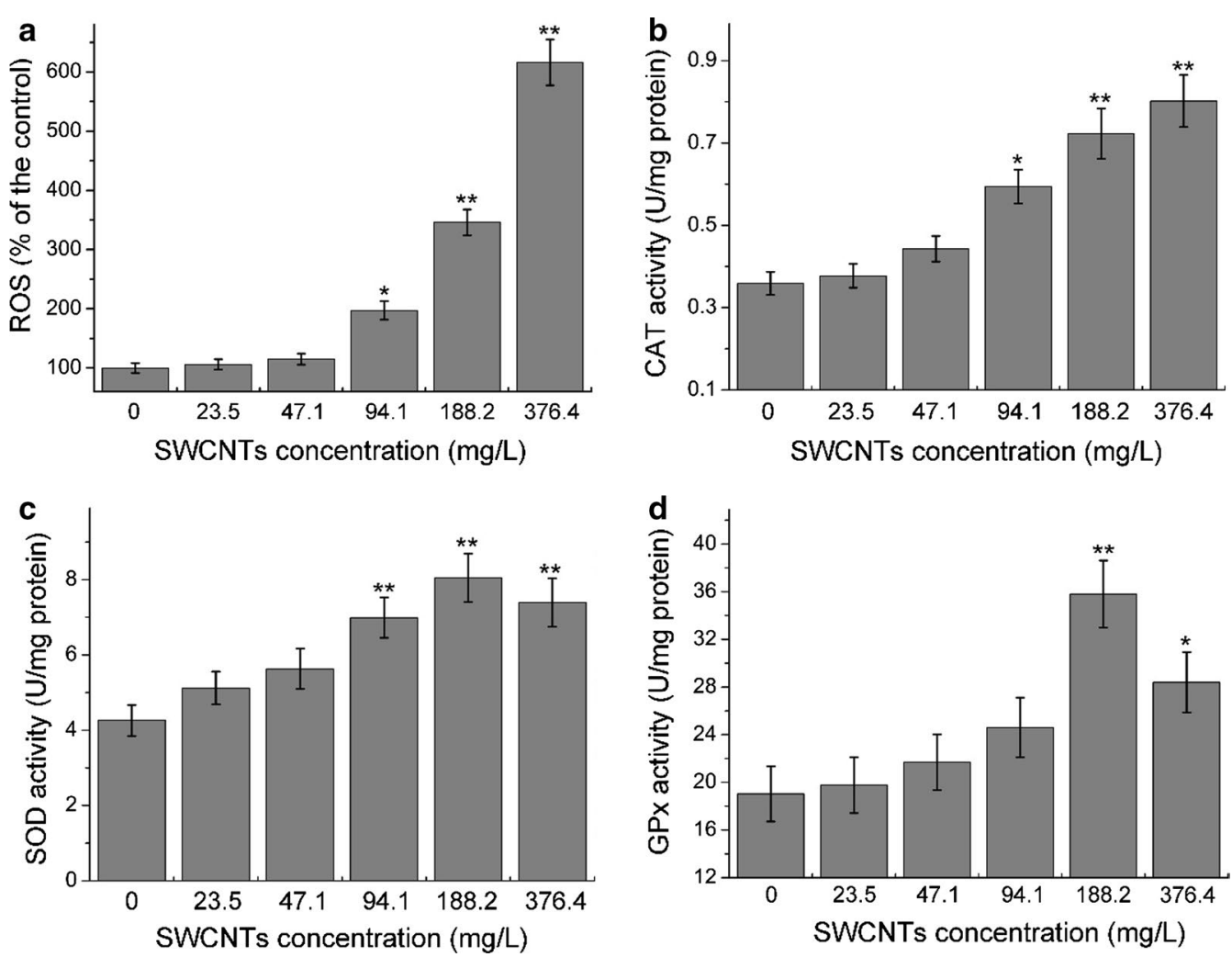

Fig. 6 Effects of O-SWCNTs on ROS generation (a), CAT (b), SOD (c) and GPx (d) activities. Values are presented as mean \pm SD. Values that are significantly different from the controls are indicated by asterisks (one-way ANOVA, ${ }^{*} p<0.05 ;{ }^{* *} p<0.01$ ) 
by decreases. Increases of CAT, SOD and GPx activities may be due to responses to the superoxide, high antioxidant enzymes activities can efficiently degrade superoxide. Decreases of SOD and GPx activities may be due to the depletion of SOD and GPx, or decrease in cell viability. Similar phenomenon was reported in other studies $[32,38]$. In general, the data indicated that oxidative stress was induced following exposure to O-SWCNTs.

\section{Cell apoptosis}

Several studies reported that SWCNTs can induce cell apoptosis/necrosis. Besides, one of the most common SWCNTs mechanisms that lead to cytotoxicity is related to oxidative stress that can cause mitochondrial impairment and apoptosis $[9,36]$. For example, Cheng et al. [9] investigated the effect of SWCNTs on rat aorta endothelial cells and demonstrated that SWCNTs induced apoptosis in the cells. Moreover, they also showed that ROS generation was involved in activation of the mitochondria-dependent apoptotic pathway [9]. To study whether O-SWCNTs can induce cellular apoptosis/necrosis, Annexin V/PI staining was performed and analyzed by flow cytometry. As shown in Fig. 7, there was no obvious apoptosis following exposure to $0-94.1 \mathrm{mg} / \mathrm{L}$. However, it showed a significant increase $(p<0.01)$ after exposure to $188.2(11.5 \%)$ and $376.4(20.8 \%) \mathrm{mg} / \mathrm{L}$ for $24 \mathrm{~h}$ compared with the control. The data indicated that the increase of mortality was related to apoptosis.

\section{Mitochondrial transmembrane potential}

Mitochondria have been suggested to play a key role in the apoptotic process. Their control of apoptosis has been described as: (1) maintenance of ATP production; (2) MTP and mitochondrial membrane permeability for the release of certain apoptogenic factors from the intermembrane space into the cytosol [24]. Reduction in MTP has been postulated to be an early and obligate event in the apoptotic signaling pathway [43]. In the study, changes of MTP after exposure to O-SWCNTs suspensions for $24 \mathrm{~h}$ were measured using JC-1 staining. As shown in Fig. 8a, MTP was significantly decreased $(p<0.01)$ at $376.4 \mathrm{mg} / \mathrm{L}$ compared with the control, indicating that the apoptosis induced by O-SWCNTs was related to mitochondrial impairment. The result is in accordance with previous studies $[9,36]$.

\section{Leakage of cytochrome $\mathrm{c}$ from mitochondria}

Decrease of MTP is associated with the opening of the mitochondria permeability transition pore. Mitochondria become so permeable that they are unable to maintain a sufficient force to retain cytochrome c (Cyt c), thus, Cyt $\mathrm{c}$ will release from the mitochondria into the cytoplasm. Contents of Cyt c in cytoplasm were detected in the

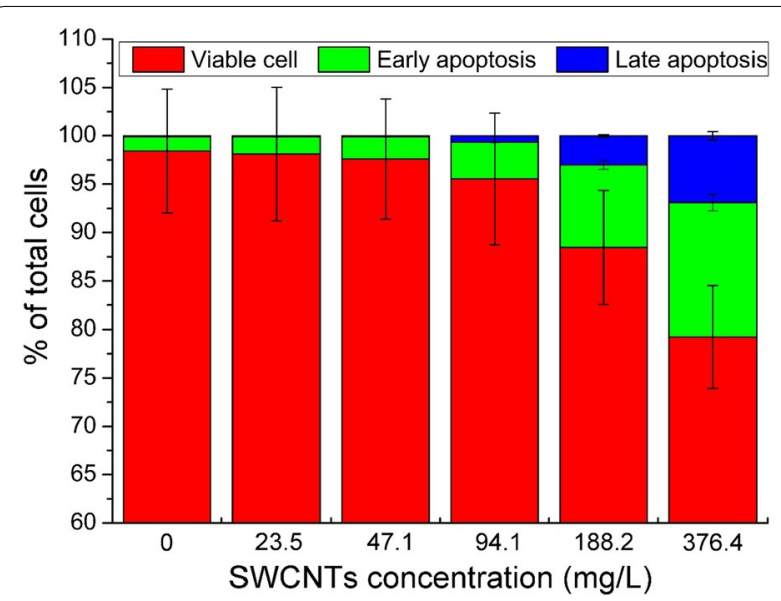

Fig. 7 Flow cytometric analysis of apoptosis using Annexin V/PI staining. The annexin $\mathrm{V}-\mathrm{FITC}^{-} / \mathrm{PI}^{-}$, annexin $\mathrm{V}-\mathrm{FITC}^{+} / \mathrm{PI}^{-}$and annexin $\mathrm{V}-\mathrm{FITC}^{+} / \mathrm{PI}^{+}$populations were regarded as viable cells, early apoptosis and late apoptosis, respectively. Values are presented as mean \pm SD

study. As shown in Fig. 8b, significant increases in Cyt c were observed compared with the control after exposure to 188.2 and $376.4 \mathrm{mg} / \mathrm{L}$. The result indicated that mitochondrial membrane permeability was increased, and Cyt c was released from mitochondria to cytoplasm following exposure to O-SWCNTs.

\section{Expression of apoptosis-related genes}

Superoxide dismutase gene encodes superoxide dismutase, which is a crucial enzyme in removing superoxide anion. It is sensitive to a variety of stress agents due to escalated oxidative stress. Moreover, it also plays a key role in the apoptotic process [21]. Yca1 mediates the apoptotic process, and encodes a yeast protein with structural homology and similar function to mammalian caspases [26]. Nma111 encodes a protein which belongs to the HtrA family of serine proteases, and its pro-apoptotic activity depends on its serine-protease activity [13]. Nuc1 has roles in mitochondrial recombination and apoptosis [5]. Expressions of SOD (Fig. 8c), Yca1 (Fig. 8d), Nma111 (Fig. 8e) and Nuc1 (Fig. 8f) were significantly increased following exposure to O-SWCNTs, indicating that $S$. cerevisiae cells were undergone apoptosis related to oxidative stress and mitochondrial impairment. The findings were consistent with previous studies $[9,30]$.

\section{Conclusion}

Taken together, results so far indicated that: (1) O-SWCNTs $(<47.1 \mathrm{mg} / \mathrm{L})$ show no obvious effects on $S$. cerevisiae cells; (2) O-SWCNTs can internalize in S. cerevisiae cells and distribute in cytoplasm, vesicles, lysosomes and cell nucleus; (3) internalization of O-SWCNTs in S. cerevisiae cells via direct penetration and endocytosis; (4) 

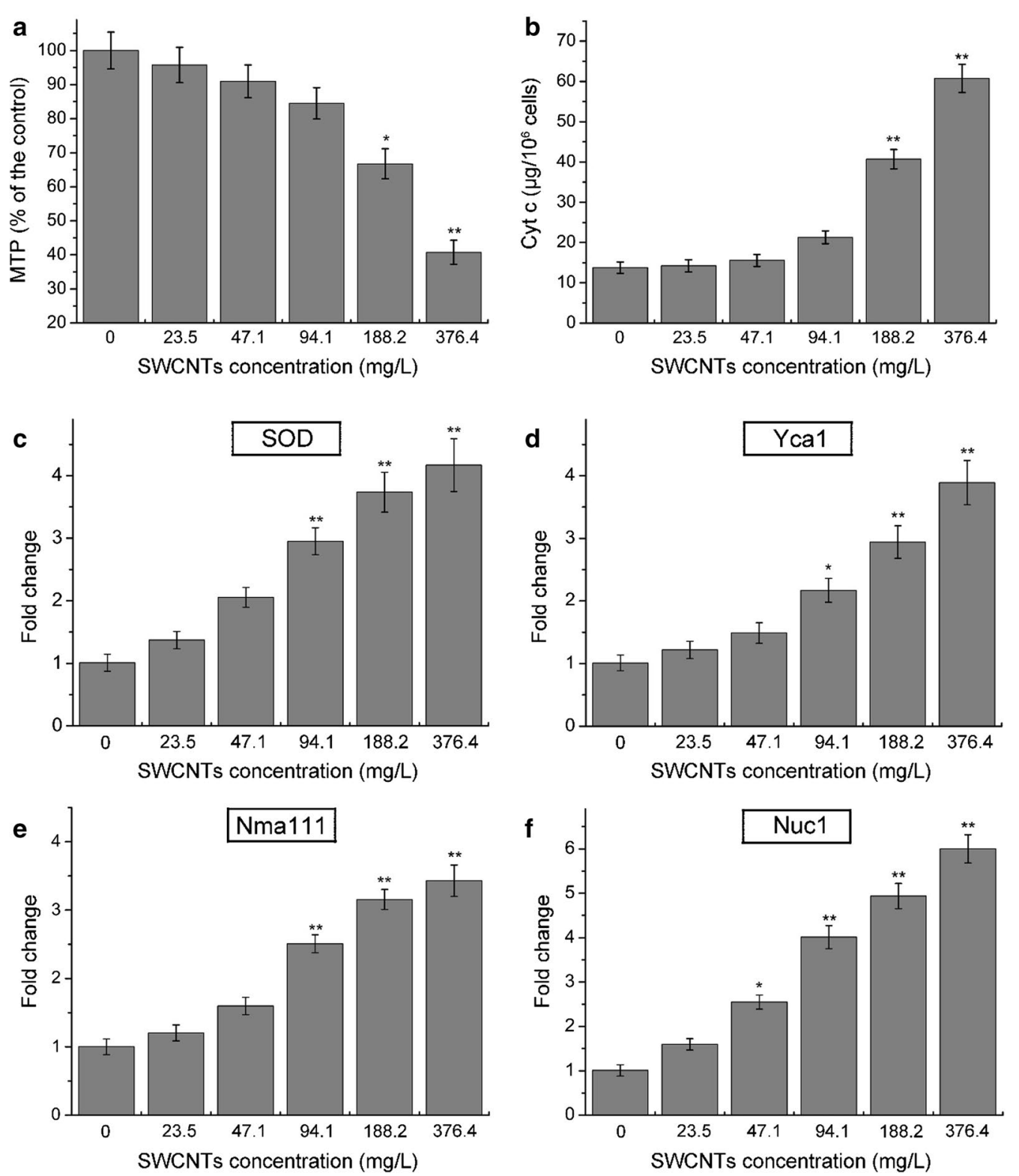

Fig. 8 a Mitochondrial transmembrane potential (MTP) of S. cerevisiae cells was evaluated using JC-1, and measured by microplate reader. b Contents of cytochrome c in cytoplasm after exposure to 0-376.4 mg/L O-SWCNTs. Expressions of SOD (c), Yca1 (d), Nma111 (e) and Nuc1 (f) following exposure to O-SWCNTs $(0-376.4 \mathrm{mg} / \mathrm{L})$. Values are presented as mean \pm SD. Values that are significantly different from the control are indicated by asterisks (one-way ANOVA, ${ }^{* *} p<0.01$ )

the maximum content of O-SWCNTs in S. cerevisiae cells is reached at $18 \mathrm{~h}$ after exposure; (5) O-SWCNTs (188.2 and $376.4 \mathrm{mg} / \mathrm{L}$ ) induce apoptosis in S. cerevisiae cells, and oxidative stress is involved in activation of the mitochondria-dependent apoptotic pathway.

\section{Abbreviations}

SEM: scanning electron microscope; TEM: transmission electron microscope; XPS: X-ray photoelectron spectroscopy; PBS: phosphate buffer solution; ROS: reactive oxygen species; SOD: superoxide dismutase; CAT: catalase; GPX: glutathione peroxidase.

\section{Authors' contributions}

$\mathrm{SZ}$ and FL performed the experimental work. JL contributed to the analysis and representation of data. SZ wrote the manuscript. All authors revised the manuscript. BZ and GXW designed the study. All authors read and approved the final manuscript.

\section{Competing interests}

The authors declare that they have no competing interests. 


\section{Availability of data and materials}

All data generated or analyzed during this study are included in this published article.

\section{Consent for publication}

All authors agree to be published.

\section{Ethics approval and consent to participate}

Not applicable.

\section{Funding}

This work was supported by the National Natural Science Foundation of China (No. U1701233), the Special Funds for Talents in Northwest A\&F University to B. Zhu (Program No. Z111021510), the special grade of the financial support from the China Postdoctoral Science Foundation (Program No. 2016T90956) and the Fundamental Research Funds for the Central Universities (Program No. 2452017078).

\section{Publisher's Note}

Springer Nature remains neutral with regard to jurisdictional claims in published maps and institutional affiliations.

Received: 22 November 2017 Accepted: 16 April 2018

Published online: 25 April 2018

\section{References}

1. Al-Jamal KT, Nerl H, Müller KH, Ali-Boucetta H, Li S, Haynes PD, Jinschek JR, Prato M, Bianco A, Kostarelos K. Cellular uptake mechanisms of functionalised multi-walled carbon nanotubes by 3D electron tomography imaging. Nanoscale. 2011;3:2627-35

2. Alshehri R, Ilyas AM, Hasan A, Arnaout A, Ahmed F, Memic A. Carbon nanotubes in biomedical applications: factors, mechanisms and remedies of toxicity. J Med Chem. 2016:59:8149-67.

3. Amenta V, Aschberger K. Carbon nanotubes: potential medical applications and safety concerns. Wiley Interdiscip Rev Nanomed Nanobiotechnol. 2015;7:371.

4. Anoshkin IV, Nefedova II, Lioubtchenko DV, Nefedov IS, Räisänen AV. Single walled carbon nanotube quantification method employing the Raman signal intensity. Carbon. 2017;116:547-52.

5. Büttner S, Eisenberg T, Carmonagutierrez D, Ruli D, Knauer H, Ruckenstuh C, Sigrist C, Wissing S, Kollroser M, Fröhlich KU. Endonuclease G regulates budding yeast life and death. Mol Cell. 2007;25:233.

6. Bayat N, Rajapakse K, Marinseklogar R, Drobne D, Cristobal S. The effects of engineered nanoparticles on the cellular structure and growth of Saccharomyces cerevisiae. Nanotoxicology. 2014;8:363-73.

7. Carmona-Gutierrez D, Eisenberg T, Büttner S, Meisinger C, Kroemer G, Madeo F. Apoptosis in yeast: triggers, pathways, subroutines. Cell Death Differ. 2010;17:763-73.

8. Cavalieri E, Rigo A, Bonifacio M, Prati ACD, Guardalben E, Bergamini C, Fato R, Pizzolo G, Suzuki H, Vinante F. Pro-apoptotic activity of a-bisabolol in preclinical models of primary human acute leukemia cells. J Transl Med. 2011;9:45

9. Cheng WW, Lin ZQ, Wei BF, Zeng Q, Han B, Wei CX, Fan XJ, Hu CL, Liu $\mathrm{LH}$, Huang $\mathrm{JH}$. Single-walled carbon nanotube induction of rat aortic endothelial cell apoptosis: reactive oxygen species are involved in the mitochondrial pathway. Int J Biochem Cell Biol. 2011;43:564.

10. De Volder MF, Tawfick SH, Baughman $\mathrm{RH}$, Hart AJ. Carbon nanotubes: present and future commercial applications. Science. 2013;339:535-9.

11. Dresselhaus MS, Dresselhaus G, Saito R, Jorio A. Raman spectroscopy of carbon nanotubes. Phys Rep. 2005:409:47-99.

12. Ema M, Gamo M, Honda K. A review of toxicity studies of single-walled carbon nanotubes in laboratory animals. Regul Toxicol Pharmacol Rtp. 2016;74:42

13. Fahrenkrog B, Sauder U, Aebi U. The S. cerevisiae HtrA-like protein Nma111p is a nuclear serine protease that mediates yeast apoptosis. J Cell Sci. 2004:117:115-26.
14. Garcíasaucedo C, Field JA, Oterogonzalez L, Sierraálvarez R. Low toxicity of $\mathrm{HfO}_{2}, \mathrm{SiO}_{2}, \mathrm{Al}_{2} \mathrm{O}_{3}$ and $\mathrm{CeO}_{2}$ nanoparticles to the yeast, Saccharomyces cerevisiae. J Hazard Mater. 2011:192:1572-9.

15. Goffeau A. Four years of post-genomic life with 6000 yeast genes. FEBS Lett. 2000:480:37-41.

16. Han A, Lefrant S. A correlated method for quantifying mixed and dispersed carbon nanotubes: analysis of the Raman band intensities and evidence of wavenumber shift. J Raman Spectrosc. 2005;36:400-8.

17. Heister E, Brunner EW, Dieckmann GR, Jurewicz I, Dalton AB. Are carbon nanotubes a natural solution? Applications in biology and medicine. ACS Appl Mater Interfaces. 2013:5:1870-91.

18. Jafar A, Alshatti Y, Ahmad A. Carbon nanotube toxicity: the smallest biggest debate in medical care. Cogent Med. 2016;3:1-12.

19. Jin H, Heller DA, Strano MS. Single-particle tracking of endocytosis and exocytosis of single-walled carbon nanotubes in NIH-3T3 cells. Nano Lett 2008:8:1577-85.

20. Kasemets K, Ivask A, Dubourguier HC, Kahru A. Toxicity of nanoparticles of $\mathrm{ZnO}, \mathrm{CuO}$ and $\mathrm{TiO}_{2}$ to yeast Saccharomyces cerevisiae. Toxicol Vitro. 2009;23:1116

21. Kwolek-Mirek M, Zadrą-Tęcza R, Bednarska S, Bartosz G. Acroleininduced oxidative stress and cell death exhibiting features of apoptosis in the yeast Saccharomyces cerevisiae deficient in SOD1. Cell Biochem Biophys. 2014;71:1525-36.

22. Long Z, Ji J, Yang K, Lin D, Wu F. Systematic and quantitative investigation of the mechanism of carbon nanotubes' toxicity toward algae. Environ Sci Technol. 2012;46:8458-66.

23. Lucero , Penalver E, Moreno E, Lagunas R. Moderate concentrations of ethanol inhibit endocytosis of the yeast maltose transporter. Appl Environ Microbiol. 1997:63:3831-6.

24. Ly JD, Grubb DR, Lawen A. The mitochondrial membrane potential (deltapsi(m)) in apoptosis; an update. Apoptosis Int J Progr Cell Death 2003:8:115

25. Møller P, Christophersen DV, Jensen DM, Kermanizadeh A, Roursgaard M, Jacobsen NR, Hemmingsen JG, Danielsen PH, Cao Y, Jantzen K. Role of oxidative stress in carbon nanotube-generated health effects. Arch Toxicol. 2014;88:1939-64.

26. Madeo F, Herker E, Maldener C, Wissing S, Lächelt S, Herlan M, Fehr M, Lauber K, Sigrist SJ, Wesselborg S. A caspase-related protease regulates apoptosis in yeast. Mol Cell. 2002;9:911-7.

27. Meng L, Zhang X, Lu Q, Fei Z, Dyson PJ. Single walled carbon nanotubes as drug delivery vehicles: targeting doxorubicin to tumors. Biomaterials. 2012:33:1689-98.

28. Miyata Y, Mizuno K, Kataura H. Purity and defect characterization of single-wall carbon nanotubes using raman spectroscopy. J Nanomater, 2011,(2010-12-05). 2010;2011:84-95.

29. Mu Q, Broughton DL, Yan B. Endosomal leakage and nuclear translocation of multiwalled carbon nanotubes: developing a model for cell uptake. Nano Lett. 2009;9:4370-5.

30. Naserzadeh P, Ghanbary F, Seydi E, Ghasemi A, Joghataei MT, Ashtari K, Akbari M. Mitochondrial oxidative stress and dysfunction induced by single- and multi-wall carbon nanotubes: a comparative study. J Biomed Mater Res Part A. 2017;105:2047-55.

31. Neves V, Heister E, Costa S, Tîlmaciu C, Borowiak-Palen E, Giusca CE, Flahaut E, Soula B, Coley HM, McFadden J. Uptake and release of double-walled carbon nanotubes by mammalian cells. Adv Func Mater. 2010:20:3272-9.

32. Oncel I, Yurdakulol E, Keleş Y, Kurt L, Yildiz A. Role of antioxidant defense system and biochemical adaptation on stress tolerance of high mountain and steppe plants. Acta Oecol. 2004;26:211-8.

33. Ong L-C, Chung FF-L, Tan Y-F, Leong C-O. Toxicity of single-walled carbon nanotubes. Arch Toxicol. 2016:90:103-18.

34. Otero-González L, García-Saucedo C, Field JA, Sierra-Álvarez R. Toxicity of $\mathrm{TiO}_{2}, \mathrm{ZrO}_{2}, \mathrm{Fe}^{0}, \mathrm{Fe}_{2} \mathrm{O}_{3}$, and $\mathrm{Mn}_{2} \mathrm{O}_{3}$ nanoparticles to the yeast, Saccharomyces cerevisiae. Chemosphere. 2013;93:1201-6.

35. Pan Y, Leifert A, Ruau D, Neuss S, Bornemann J, Schmid G, Brandau W, Simon U, Jahnen-Dechent W. Gold nanoparticles of diameter $1.4 \mathrm{~nm}$ trigger necrosis by oxidative stress and mitochondrial damage. Small. 2009;5:2067-76.

36. Park EJ, Zahari NEM, Kang MS, Sang JL, Lee K, Lee BS, Yoon C, Cho MH, Kim Y, Kim JH. Toxic response of HIPCO single-walled carbon nanotubes in mice and RAW264.7 macrophage cells. Toxicol Lett. 2014;229:167-77. 
37. Porter AE, Gass M, Muller K, Skepper JN, Midgley PA, Welland M. Direct imaging of single-walled carbon nanotubes in cells. Nat Nanotechnol. 2007;2:713.

38. Radu M, Munteanu MC, Petrache S, Serban Al, Dinu D, Hermenean A, Sima C, Dinischiotu A. Depletion of intracellular glutathione and increased lipid peroxidation mediate cytotoxicity of hematite nanoparticles in MRC-5 cells. Acta Biochim Pol. 2010;57:355-60.

39. Salzmann CG, Chu BT, Tobias G, Llewellyn SA, Green ML. Quantitative assessment of carbon nanotube dispersions by Raman spectroscopy. Carbon. 2007:45:907-12.

40. Schmittgen TD, Livak KJ. Analyzing real-time PCR data by the comparative CT method. Nat Protoc. 2008;3:1101-8.

41. Sohn EK, Chung YS, Johari SA, Kim TG, Jin KK, Ji HL, Yong HL, Kang SW, Yu IJ. Acute toxicity comparison of single-walled carbon nanotubes in various freshwater organisms. Biomed Res Int. 2015;2015:1-7.

42. Stone MB. Differential uptake of carbon nanoparticles by plant and Mammalian cells. Small. 2010;6:612.
43. Zamzami N, Marchetti P, Castedo M, Zanin C, Vayssière JL, Petit PX, Kroemer $\mathrm{G}$. Reduction in mitochondrial potential constitutes an early irreversible step of programmed lymphocyte death in vivo. J Exp Med. 1995;181:1661

44. Zhu B, Liu GL, Ling F, Song LS, Wang GX. Development toxicity of functionalized single-walled carbon nanotubes on rare minnow embryos and larvae. Nanotoxicology. 2014;9:1-12

45. Zhu S, Luo F, Zhu B, Wang GX. Toxicological effects of graphene oxide on Saccharomyces cerevisiae. Toxicol Res. 2017a.

46. Zhu S, Luo F, Zhu B, Wang GX. Mitochondrial impairment and oxidative stress mediated apoptosis induced by a- $\mathrm{Fe}_{2} \mathrm{O}_{3}$ nanoparticles in Saccharomyces cerevisiae. Toxicology Research. 2017b; 6 .

47. Zhu S, Zhu B, Huang A, Hu Y, Wang G, Ling F. Toxicological effects of multi-walled carbon nanotubes on Saccharomyces cerevisiae: the uptake kinetics and mechanisms and the toxic responses. J Hazard Mater. 2016:318:650-62
Ready to submit your research? Choose BMC and benefit from:

- fast, convenient online submission

- thorough peer review by experienced researchers in your field

- rapid publication on acceptance

- support for research data, including large and complex data types

- gold Open Access which fosters wider collaboration and increased citations

- maximum visibility for your research: over $100 \mathrm{M}$ website views per year

At $\mathrm{BMC}$, research is always in progress.

Learn more biomedcentral.com/submissions 